\title{
Lack of tax diversity for tropical spastic paraparesis/human T-cell lymphotropic virus type 1 (HTLV-I) associated myelopathy development in HTLV-I-infected subjects in São Paulo, Brazil
}

\author{
J Casseb/*/+ , LMI Fukumori**, M PP Vergara, S Sanabani*, PE Marchiori***, \\ AJS D uarte*, ACP de O liveira
}

\begin{abstract}
Ambulatório de HTLV, Instituto de Infectologia "Emílio Ribas, Av. Dr. Enéas de Carvalho Aguiar 500, 3 o andar, 05403-000 São Paulo, SP, Brasil *Laboratório de Investigação em Imunologia e Dermatologia, Faculdade de Medicina, Universidade de São Paulo, São Paulo, Brasil **Fundação Hemocentro de São Paulo, São Paulo, SP, Brasil ***Divisão de Neurologia, Hospital das Clínicas, Faculdade de Medicina, Universidade de São Paulo, São Paulo, SP, Brasil
\end{abstract}

The product of human T-cell lymphotropic virus type 1 (HTLV-1) tax gene has a transactivating effect of the viral and cellular gene expression. Genetic variations in this gene have been correlated with differences in clinical outcomes. Based upon its diversity, two closely related substrains, namely $\operatorname{tax} A$ and $\operatorname{tax} B$, have been described. The $\operatorname{tax} A$ substrain has been found at a higher frequency among human T-cell leukemia virus type 1 (TSP/HAM) patients than among healthy HTLV-I-infected asymptomatic subjects in Japan. In this study, we determined the distribution of tax substrains in HTLV-I-infected subjects in the city of São Paulo, Brazil. Using the ACCII restriction enzyme site, we detected only tax A substrain from 48 TSP/HAM patients and 28 healthy HTLV-I carriers. The sequenced tax genes from nine TSP/HAM patients and five asymptomatic HTLV-I carriers showed a similar pattern of mutation, which characterizes tax A. Our results indicate that HTLV-I tax subtypes have no significant influences on TSP/HAM disease progression. Furthermore, monophyletic introduction of HTLV-I to Brazil probably occurred during the African slave trade many years ago.

Key words: human T-cell lymphotropic virus type 1 - tropical spastic paraparesis/human T-cell lymphotropic virus type 1 associated myelopathy - tax subtypes - Brazil

Human T-cell lymphotropic virus type 1 (HTLV-I) has been implicated as a causative agent of adult T-cell leukemia/lymphoma (ATL) and a severely incapacitating neurological disease called tropical spastic paraparesis/HTLVI-associated myelopathy (TSP/HAM) in 0.2 to 5 of every 100 infected subjects (Kaplan et al. 1990). HTLV-I infection is lifelong, and the virus may be transmitted by breastfeeding at birth, or through sexual contacts or blood transfusions later in life (Manns et al. 1992, 1999). Brazil is considered to be an endemic area for HTLV-I, with infections ranging from $0.5 \%$ in the South to $1.5 \%$ in the Northeast (Segurado et al. 1997, Galvão-Castro et al. 1997). HTLVI-associated illnesses, such as TSP/HAM and ATL, have been described in different areas of the country (Castro et al. 1989, de Oliveira et al. 1990, Araujo et al. 1998).

Molecular variability studies of the virus full genomes obtained from different geographical locations indicated that HTLV-1 isolates have very low variable genomes $(0.5$ to 3\%) (Gessain et al. 1992, 1993, Nerurkar et al. 1993). Despite these highly conserved genomes, HTLV-I viruses are phylogenetically classified into three major lineages:

Financial support: Fapesp 99/11188-1, 00/12761-6, and 03/ 08901-5, CNPq 3012242/02-5, Fundação Faculdade de Medicina

+Corresponding author: jorge_casseb@yahoo.com.br

Received 22 November 2005

Accepted 12 April 2006
Melanesian, Central African, and Cosmopolitan. The Cosmopolitan group is further subdivided into four subgroups: Transcontinental (A), Japanese (B), West African (C), and North African (D), on the basis of variations in the long terminal repeat (LTR). In Brazil, only a few studies have been done on HTLV-I diversity, usually using LTR sequencing data for subtyping (Segurado et al. 2002).

It has been suggested that molecular mimicry mechanism between immunodominant epitopes of tax and neuronal heterogeneous nuclear ribonucleoprotein A1 (hnRNP A1) may drive the TSP/HAM pathogenesis (Levin et al. 2002). Therefore, existence of such mechanism may help the virus to evade the host defense and allow it to establish itself and be maintained as a persistent infection. Two substrains of HTLV-I, $\operatorname{tax} \mathrm{A}$ and $\operatorname{tax} \mathrm{B}$, have been previously described (Furukawa et al. 2000), based on four characteristic mutations at specific positions in the tax gene. These mutations have been shown to differentiate $\operatorname{tax} \mathrm{A}$ from the prototypic strain ATK. This classification may have clinical importance since the tax A substrain was found in higher frequency among TSP/HAM (84\%) patients compared to $28 \%$ of HTLV-I-asymptomatic carriers in Kagoshima, Japan. Thus, individuals with a combination of high HTLV-I proviral DNA load, absence of HLA$\mathrm{A} * 02$, and the presence of $\operatorname{tax} \mathrm{A}$, possess a 2.5 -fold higher risk for development of TSP/HAM (Furukawa et al. 2000). In this study, we performed an analysis on some Brazilian isolates obtained from HTLV-I-infected subjects to determine whether they contained these substrain-distinct mutations. 


\section{MATERIALS AND METHODS}

The study included blood samples from 28 adult asymptomatic HTLV carriers and 48 TSP/HAM cases from the HTLV out-patients clinic at the Institute of Infectious Diseases "Emílio Ribas" and at the Hospital das Clínicas, Medical School, University of São Paulo. There were 35 males and 35 females with median age of 42 years old ranging from 18-70 years of age. The diagnostic criteria for TSP/HAM was based on the World Health Organization (WHO) diagnostic criteria (Osame 1990). HTLV-I infection was confirmed by Western-Blotting (HTLV-I WB, Genelabs, Singapore), and/or polymerase chain reaction (PCR). All subjects were informed and consented to the study, and an approval was provided by the institutional ethical research board.

Peripheral blood was collected using EDTA anticoagulant and peripheral blood mononuclear cells (PBMCs) were separated by ficoll-hypaque centrifugation. DNA was extracted from one million PBMCs using a commercial kit (GFX, Pharmacia, Uppsala, Sweden). The extracted DNA was used as a template to amplify the whole tax gene by nested PCR fashion using primers and methods described elsewhere (Furukawa et al. 2000). The restriction of fragment length polymorphism (RFLP) by ACCII restriction enzyme was used to distinguish tax $\mathrm{A}$ from tax $\mathrm{B}$ substrain. The presence of cleavage among the $\operatorname{tax} \mathrm{B}$, relative to ATK strain, indicates a mutation site.

Both complementary strands of the tax gene were directly sequenced from nine TSP/HAM patients and five asymptomatic HTLV-I carriers using internal primers, fluorescent dye terminators, and Taq polymerase on an auto- mated sequencer (ABI 377, Applied Biosystems, Foster city, CA, US). Sequences were aligned with reference sequences using the program Clustal $\mathrm{X}$. The alignment was optimized and translated into amino acid with the BioEdit software.

\section{RESULTS}

The transmission history. Eleven subjects had acquired their HTLV-I infection through intravenous drug use and 65 were infected through heterosexual contact or breast-feeding. Nine patients were co-infected with HIV-1 and 13 with hepatitis $C$ virus and none was Asiatic origin.

Using RFLP analysis with AcII restriction site, we determined that all the samples (48 TSP/HAM patients and 28 healthy HTLV-I carriers) belonged to the tax A substrain. Furthermore, the nucleotide and amino acid sequences from the tax region of 14 subjects (nine TSP/HAM cases and five asymptomatic healthy HTLV-I-carriers) showed patterns of mutation consistent with $\operatorname{tax} \mathrm{A}$ as depicted in the Table. The Table also showed two additional nucleotide substitutions at position 7401 and 7914 in $87.5 \%$ of our subjects. Only two mutation points were observed in the entire tax gene sequence, which were cleaved by the AcII restriction enzyme. All samples showed highly conserved nucleotide sequences over the entire tax gene, and only two cleavage ACII restriction sites were found.

\section{DISCUSSION}

These findings are in accordance with a larger sampling from several areas from Brazil (Kashima et al. 2004), where only sequences with high homology (99\%) to the ATK reference strain were observed. It has been shown,

TABLE

Sequence similarity and variability among human T cell lymphotropic virus type 1 (HTLV-I) samples from different sources. A summary of proviral DNA sequence analysis over the whole tax region for nine tropical spastic paraparesis/HTLV-I associated myelopathy patients and five HTLV-I-infected asymptomatic subjects compared with ATK prototypic strain and consensus sequences of $\operatorname{tax} \mathrm{A}$ and $\operatorname{tax} \mathrm{B}$ from previously published data (Furukawa et al. 2000). Shadowed nucleotides indicate difference from ATK strain. The positional nomenclature of the tax region corresponds to sequence alignment with ATK strain

\begin{tabular}{|c|c|c|c|c|c|c|}
\hline \multirow[b]{3}{*}{ Isolates } & \multicolumn{5}{|c|}{ Tax gene } & \multirow[b]{3}{*}{ Tax substrain } \\
\hline & 7401 & 7914 & 7920 & 7982 & 8231 & \\
\hline & $\mathrm{D}$ & I & $\mathrm{L}$ & $\mathrm{A} \rightarrow \mathrm{V}$ & $\mathrm{S} \rightarrow \mathrm{N}$ & \\
\hline ATK & $\mathrm{C}$ & $\mathrm{T}$ & $\mathrm{C}$ & $\mathrm{C}$ & $\mathrm{G}$ & Prototype strain \\
\hline Consensus $\operatorname{tax} \mathrm{B}$ & $\mathrm{C}$ & $\mathrm{T}$ & $\mathrm{C}$ & $\mathrm{C}$ & G & $\mathrm{B}$ \\
\hline Consensus tax A & $\mathrm{C}$ & $\mathrm{T}$ & $\mathrm{T}$ & $\mathrm{T}$ & A & A \\
\hline TSP165 & $\mathrm{T}$ & $\mathrm{C}$ & $\mathrm{T}$ & $\mathrm{T}$ & A & A \\
\hline TSP168 & $\mathrm{T}$ & $\mathrm{C}$ & $\mathrm{T}$ & $\mathrm{T}$ & A & A \\
\hline TSP23 & $\mathrm{T}$ & $\mathrm{C}$ & $\mathrm{T}$ & $\mathrm{T}$ & A & A \\
\hline TSP33 & $\mathrm{T}$ & $\mathrm{C}$ & $\mathrm{T}$ & $\mathrm{T}$ & A & A \\
\hline TSP124 & $\mathrm{T}$ & $\mathrm{C}$ & $\mathrm{T}$ & $\mathrm{T}$ & A & A \\
\hline TSP126 & $\mathrm{C}$ & $\mathrm{T}$ & $\mathrm{T}$ & $\mathrm{T}$ & A & A \\
\hline TSP262D & $\mathrm{T}$ & $\mathrm{C}$ & $\mathrm{T}$ & $\mathrm{T}$ & A & A \\
\hline TSP261 & $\mathrm{T}$ & $\mathrm{C}$ & $\mathrm{T}$ & $\mathrm{T}$ & A & A \\
\hline TSP318B & $\mathrm{C}$ & $\mathrm{T}$ & $\mathrm{T}$ & $\mathrm{T}$ & A & A \\
\hline AS174E & $\mathrm{T}$ & $\mathrm{C}$ & $\mathrm{T}$ & $\mathrm{T}$ & A & A \\
\hline AS230B & $\mathrm{T}$ & $\mathrm{C}$ & $\mathrm{T}$ & $\mathrm{T}$ & A & A \\
\hline AS257 & $\mathrm{T}$ & $\mathrm{C}$ & $\mathrm{T}$ & $\mathrm{T}$ & A & A \\
\hline AS368 & $\mathrm{T}$ & $\mathrm{C}$ & $\mathrm{T}$ & $\mathrm{T}$ & A & A \\
\hline AS232D & $\mathrm{T}$ & $\mathrm{C}$ & $\mathrm{T}$ & $\mathrm{T}$ & A & A \\
\hline
\end{tabular}


using RFLP on samples from the LTR region, that the majority of patients from São Paulo belonged to the Cosmopolitan A subtype, although other LTR subtypes are also present in this population (Yamashita et al. 1999, Segurado et al. 2002).

The mere detection of tax sub-strain A in our cohort and the high prevalence of viral infection among the African descendents in the North and Northeast of the country (Bendelt et al. 2001, Alcantara et al. 2003, Laurentino et al. 2005) support the hypothesis that the Brazilian isolates originated from African origin. Moreover, detection of tax sub-strain A among some of our subjects that considered to be descendents of native Asian population from Japan indicates that these individuals or their relatives came from areas where this sub-strain predominates in Japan.

Finally, we found no association between tax diversity and HTLV-I disease progression, as observed in Japan (Furukawa et al. 2000). It is possible that our small sample size had no power to detect additional mutation point over the entire tax gene. However, it is more feasible to consider TSP/HAM as an immune mediated illness associated with some HLA typing susceptibility and high viral load at the beginning of the symptoms. These findings may help to understand the HTLV-I diversity in Brazil and for vaccine development since tax region is crucial in the virus life cycle and pathogenesis.

\section{ACKNOWLEDGMENTS}

To Dana Gallo for critical review of the manuscript.

\section{REFERENCES}

Alcantara Jr LC, Van Dooren S, Gonçalves MS, Kashima S, Cosia MC, Santos FL, Bittencourt AL, Dourado I, Filho AA, Covas DT, Vandamme AM, Galvão-Castro B 2003. Globin haplotypes of human T-cell lymphotropic virus type I infected individuals in Salvador, Bahia, Brazil, suggest a post-Colomabian African origin of this virus. J Acq Imm Def Synd Hum Retrov 33: 536-542.

Araujo AQ, Andrade-Filho AS, Castro-Costa CM, MennaBarreto M, Almeida SM 1998. HTLV-I-associated myelopathy/tropical spastic paraparesis in Brazil: a nationwide survey. HAM/TSP Brazilian Study Group. J Acquir Immune Defic Syndr Hum Retrovirol 19: 536-541.

Bandelt HJ, Alves-Silva J, Guimarães PE, Santos MS, Brehm A, Pereira L, Coppa A, Larruga JM, Rengo C, Scozzari R, Torroni A, Prata MJ, Amorim A, Prado VF, Pena SD 2001. Phylogeography of the human mitochondrial haplogroup L3e: a snapshot of African prehistory and Atlantic slave trade. Ann Hum Genet 65: 549-563.

Castro LH, Chaves CJ, Callegaro D, Nobrega JP, Scaff M 1989. HTLV-I associated myelopathy in Brazil: a preliminary report. Arq Neuropsiquiatr 47: 501-502.

de Oliveira MS, Matutes E, Famadas LC, Schulz TF, Calabro ML, Nucci M, Andrada-Serpa MJ, Tedder RS, Weiss RA, Catovsky D 1990. Adult T-cell leukaemia/lymphoma in Brazil and its relation to HTLV-I. Lancet 336: 987-990.

Furukawa Y, Yamashita M, Usuku K, Izumo S, Nakagawa M, Osame M 2000. Phylogenetic subgroups of human T cell lymphotropic virus (HTLV) type I in the tax gene and their association with different risks for HTLV-I-associated myel- opathy/tropical spastic paraparesis. J Inf Dis 182: 13431349.

Galvão-Castro B, Loures L, Rodriques LG, Sereno A, Ferreira Junior OC, Franco LG, Muller M, Sampaio DA, Santana A, Passos LM, Proietti F 1997. Distribution of human Tlymphotropic virus type I among blood donors: a nationwide Brazilian study [letter]. Transfusion 37: 242-243.

Gessain A, Boeri E, Yanagihara R, Gallo RC, Franchini G 1993. Complete nucleotide sequence of a highly divergent human T-cell leukemia (lymphotropic) virus type I (HTLV-I) variant from melanesia: genetic and phylogenetic relationship to HTLV-I strains from other geographical regions. J Virol 67: 1015-1023.

Gessain A, Gallo RC, Franchini G 1992. Low degree of human T-cell leukemia/lymphoma virus type 1 genetic drift in vivo as a means of monitoring viral transmission and movement of ancient human populations. J Virol 66: 2288-2295.

Kaplan J E, Osame M, Kubota H 1990. The risk of development of HTLV-I-associated myelopathy/tropical spastic paraparesis among persons infected with HTLV-I. J Acq Imm Def Synd 3: 1096-1101.

Kashima S, Takayanagui M, Hachiya EM, Carreto R, Alcantara LC, Galvão-Castro B, Pombo-de-Oliveira M, Covas DT 2004. Molecular characterization of tax region in HTLV-I patients from Brazil. AIDS Res Hum Retrov 319 (Suppl. 19): S-29.

Laurentino RV, Lopes IGL, Azevedo VN, Machado LFA, Moreira MRC, Lobato L, Ishak MOG, Ishak R, Vallinoto ACR 2005. Molecular characterization of human T-cell lymphotropic virus coinfecting human immunodeficiency virus 1 infected patients in the Amazon region of Brazil. Mem Inst Oswaldo Cruz, 100: 371-376.

Levin MC, Lee SM, Morcos Y, Brady J, Stuart J 2002. Crossreactivity between immunodominant human Tlymphotropic virus type I tax and neurons: Implications for molecular mimicry. J Inf Dis 186: 1514-1517.

Manns A, Hisada M, La Grenade L 1999. Human Tlymphotropic virus type I infection. Lancet 353: 19511958.

Manns A, Wilks RJ, Murphy EL, Haynes G, Figueroa JP, Barnett M, Hanchard B, Blattner WA 1992. A prospective study of transmission by transfusion of HTLV-I and risk factors associated with seroconversion. Int J Cancer 51: 886-891.

Nerurkar VR, Song KJ, Saitou N, Melland RR, Yanagihara R 1993. Interfamilial and intrafamilial genomic diversity and molecular phylogeny of human T-cell lymphotropic virus type I from Papua New Guinea and the Solomon Islands. Virology 196: 506-513.

Osame M 1990. HTLV. In WA Blattner, Human Retrovirology: HTLV, Raven Press, New York, p. 191-197.

Segurado AA, Biasutti C, Zeigler R, Rodrigues C, Damas CD, Jorge ML, Marchiori PE 2002. Identification of human Tlymphotropic virus type I (HTLV-I) subtypes using restricted fragment length polymorphism in a cohort of asymptomatic carriers and patients with HTLV-I-associated myelopathy/tropical spastic paraparesis from São Paulo, Brazil. Mem Inst Oswaldo Cruz 97: 329-333. 
Segurado AA, Malaque CM, Sumita LM, Pannuti CS, Lal RB 1997. Laboratory characterization of human T cell lymphotropic virus types 1 (HTLV-1) and 2 (HTLV-2) infections in blood donors from São Paulo, Brazil. Am J Trop Med Hyg 57: 142-148.

Yamashita M, Veronesi R, Menna-Barreto M, Harrington Jr WJ, Sampio C, Brites C, Badaro R, Andrade-Filho AS,
Okhura S, Igarashi T, Takehisa J, Miura T, Chamone D, Bianchini O, Jardim C, Sonoda S, Hayami M 1999. Molecular epidemiology of human T-cell leukemia virus type I (HTLV-I) in Brazil: the predominant HTLV-Is in South America differ from HTLV-1s of Japan and Africa, as well as those of those of Japanese immigrants and their relatives in Brazil. Virology 261: 59-69. 